\title{
IDENTIFIED PLANTS WHICH ARE BELONGS IN INDIGOFERA GENERA IN THOOTHUKUDI DISTRICT, TAMIL NADU, INDIA
}

\author{
Dr. A. Rajesh ${ }^{*} \mathbb{Q}$ iD \\ ${ }^{* 1}$ Assistant Professor, Department of Medicinal Botany, Govt. Siddha Medical College, Tirunelveli, \\ India
}

DOI: https://doi.org/10.29121/granthaalayah.v8.i11.2020.2455

Article Type: Research Article

Article Citation: Dr. A. Rajesh. (2020). IDENTIFIED PLANTS

WHICH ARE BELONGS IN

INDIGOFERA GENERA IN

THOOTHUKUDI DISTRICT, TAMIL

NADU, INDIA. International Journal of Research -GRANTHAALAYAH, 8(11), 287-295.

https://doi.org/10.29121/granthaa

layah.v8.i11.2020.2455

Received Date: 15 November 2020

Accepted Date: 30 November 2020

Keywords:

Indigofera Genera

Thoothukudi

Fabaceae

\section{ABSTRACT}

The Indigofera are frequently shrubs, and some are small trees or herbaceous perennials or annuals. These have pinnate leaves. Racemes of flowers grow in the leaf axils, in hues of red, but there are a few white- and yellow-flowered species. The fruit is a legume pod of varying size and shape. Botanical description schedule as; Kingdom: Plantae, (unranked): Angiosperms, (unranked): Eudicots, (unranked): Rosids, Order: Fabales, Family: Fabaceae, Subfamily: Faboideae, Tribe: Indigofereae, Genus: Indigofera. 1620 plant name records match your search criteria Indigofera. The names found have these generic epithets: as accepted in the plant list online data base. That plants were; Indigofera argentea / I. articulate, Indigofera aspalathoides Vahl. Indigofera enneaphylla Linn. Indigofera glabra Linn. Indigofera glandulosa Willd. Indigofera linifolia Retz. Indigofera pulchella Roxb. Indigofera tinctoria Linn. Indigofera trifoliata Linn. Indigofera trita Linn. Books mentioned 04 species were not latest updated Plant List Online data base which were; Indigofera caerulea Roxb. Indigofera cordifolia. Indigofera frutescens. Indigofera hirsuta. According to the Results and Discussion this research revealed that, 20 species of Indigofera genera by the evidence of books and 04 species synonyms like updated latest in online data base. However, 16 species available in the Thoothukudi District 16 species available commonly and 04 species were rarely showed in Thoothukudi District by randomly field to all soil types of areas.

\section{INTRODUCTION}

Species of Indigofera are frequently shrubs, and some are small trees or herbaceous perennials or annuals. Most have pinnate leaves. Racemes of flowers raise in the leaf axils, in hues of red, but there are a few white- and yellowflowered species. The fruit is a legume pod of changing size and shape. [3]

Indigofera is a diverse genus that has exposed unique features production it an interesting candidate as a potential perennial crop. Specifically, there is varied variation between species with a number of distinctive characteristics. Some examples of this variety include alterations in pericarp thickness, fruit type, and flowering morphology. The unique features it has showed include potential for mixed smallholder systems with at least one other species and a resilience that allows for constant nitrogen update despite varying circumstances.

One example of its sole flowering morphology is an open carpel not often understood elsewhere. In addition, it seems that the organ primordial is often formed at deeper layers than other eudicots. [4] This diversity could have

(C) 2020 The Author(s). This is an open access article distributed under the terms of the Creative Commons Attribution License, which permits unrestricted use, distribution, and reproduction in any medium, provided the original author and source are credited. 
important insinuations on its role in an actual perennial polyculture. For example, different flowering morphologies could be insincerely selected for in varying directions in order to better fit in dissimilar environmental conditions and with different populations of other plants.

The categories of fruit formed by different species of Indigofera can also be separated into wide-ranging categories that over show great difference. The three elementary types of fruit groupings can be divided by their curvature including straight, slightly curved, and falcate (sickle-shaped). In addition, several of the species as well as Indigofera microcarpa, Indigofera suffruticosa, and Indigofera enneaphylla have exposed delayed dehiscence (ripening) of fruits [5] This variation might again permit for artificial selection of the most plentiful and nutritious fruit types and shapes.

Additional way to categorize Indigofera is by its pericarp thickness. The pericarp (the tissue from the ovary that surrounds the seeds) can be categorized as type I, type II, and type III with type I having the thinnest pericarp and smallest layers of schlerenchymatous (stiff) tissue and type III having the thickest pericarp and most schlerenchymatous layers. Despite the previous examples of delayed dehiscence, most fruits of this genus show normal irascible dehiscence to disperse seeds. [6] Similar to fruit shape, the variation in fruit sizes allows for the thickest and most bountiful fruits to be selected.

\section{Botanical classification}

$\begin{array}{ll}\text { Kingdom: } & \text { Plantae } \\ \text { (unranked): } & \text { Angiosperms } \\ \text { (unranked): } & \text { Eudicots } \\ \text { (unranked): } & \text { Rosids } \\ \text { Order: } & \text { Fabales } \\ \text { Family: } & \text { Fabaceae } \\ \text { Subfamily: } & \text { Faboideae } \\ \text { Tribe: } & \text { Indigofereae [1] } \\ \text { Genus: } & \text { Indigofera }\end{array}$

\section{Benefits: Indigo dye}

Numerous species, especially Indigofera tinctoria and Indigofera suffruticosa, are used to yield the dye indigo. Scraps of Indigo-dyed fabric likely dyed with plants from the genus Indigofera discovered at Huaca Prieta predate Egyptian indigo-dyed fabrics by more than 1,500 years. [7] Colonial planters in the Caribbean grew indigo and relocated its cultivation when they firm in the colony of South Carolina and North Carolina where people of the Tuscarora confederacy assumed the dyeing procedure for head wraps and clothing. Exports of the crop did not rise until the mid-to late 18th century. When Eliza Lucas Pinckney and enslaved Africans successfully cultivated new strains near Charleston it turn into the second most important cash crop in the colony (after rice) before the American Revolution. It covered more than one-third of all exports in value.

The chemical aniline, from which many important dyes are derivative, was first synthesized from Indigofera suffruticosa (syn. Indigofera anil, whence the name aniline).

In Indonesia, the Sundanese use Indigofera tinctoria (known locally as tarum or nila) as dye for batik. Marco Polo was the first to account on the preparation of indigo in India. Indigo was fairly frequently used in European easel painting during the Middle Ages. [8], [9]

\section{Medicinal uses}

More than a few species of this collection are used to alleviate pain. The herbs are commonly stared as an analgesic with anti-inflammatory activity, rather than an anodyne. [10] Indigofera articulata (Khedaish in Arabic) was used for toothache, and Indigofera oblongifolia (hasr in Arabic) was used as an anti-inflammatory for insect stings, snakebites, and swellings. [11]

Indigofera suffruticosa and Indigofera aspalthoides have also been utilized as anti-inflammatories. [12], [13], [14]. A obvious was granted for use of Indigofera arrecta extract to dismiss ulcer pain. [15]

The Maasai people of Kenya use parts of Indigofera brevicalyx and Indigofera swaziensis as tooth brushes. [16] 


\section{Dr. A. Rajesh}

\section{MATERIALS AND METHODS}

Research type: plant survey research

Research design: selected areas and field visit to collected samples and identified the particular genera species respectively and made digital photography of the identified plants. Data compare with available botany taxonomical printed book and www.the plant list.com in electronic media with schedule the plants as result then data generated to conclusion.

\section{RESULTS}

\begin{tabular}{|c|c|c|c|}
\hline BOTANICAL NAME & Tamil name & REFERENCE & \\
\hline Indigofera angustifolia & & $\begin{array}{l}\text { indian materia medica, volume two, 3rd } \\
\text { edition, } 1954\end{array}$ & \\
\hline Indigofera anil Linn. & shimaiya-veri & $\begin{array}{l}\text { indian materia medica, volume two, 3rd } \\
\text { edition, } 1954\end{array}$ & \\
\hline $\begin{array}{l}\text { Indigofera argentea / I. } \\
\text { articulata }\end{array}$ & $\begin{array}{l}\text { kat-averi / aramurai, } \\
\text { iruppumuri }\end{array}$ & $\begin{array}{l}\text { indian materia medica, volume two, 3rd } \\
\text { edition, } 1954\end{array}$ & 2 \\
\hline $\begin{array}{l}\text { Indigofera aspalathoides } \\
\text { Vahl. }\end{array}$ & shivanarvembu & $\begin{array}{l}\text { indian materia medica, volume two, 3rd } \\
\text { edition, } 1954\end{array}$ & 2 \\
\hline Indigofera caerulea Roxb. & & $\begin{array}{l}\text { indian materia medica, volume two, 3rd } \\
\text { edition, } 1954\end{array}$ & \\
\hline Indigofera cordifolia. & & $\begin{array}{l}\text { indian materia medica, volume two, 3rd } \\
\text { edition, } 1954\end{array}$ & \\
\hline $\begin{array}{l}\text { Indigofera enneaphylla } \\
\text { Linn. }\end{array}$ & cheppu neringie, adampedi & $\begin{array}{l}\text { indian materia medica, volume two, 3rd } \\
\text { edition, } 1954\end{array}$ & 2 \\
\hline Indigofera frutescens. & & $\begin{array}{l}\text { indian materia medica, volume two, 3rd } \\
\text { edition, } 1954\end{array}$ & \\
\hline Indigofera galegoides $D C$. & & $\begin{array}{l}\text { indian materia medica, volume two, 3rd } \\
\text { edition, } 1954\end{array}$ & \\
\hline Indigofera glabra Linn. & & $\begin{array}{l}\text { indian materia medica, volume two, 3rd } \\
\text { edition, } 1954\end{array}$ & 2 \\
\hline Indigofera glandulosa Willd. & barapatam & $\begin{array}{l}\text { indian materia medica, volume two, 3rd } \\
\text { edition, } 1954\end{array}$ & 2 \\
\hline Indigofera hirsuta. & & $\begin{array}{l}\text { indian materia medica, volume two, 3rd } \\
\text { edition, } 1954\end{array}$ & \\
\hline Indigofera indica Gaertn. & & $\begin{array}{l}\text { indian materia medica, volume two, 3rd } \\
\text { edition, } 1954\end{array}$ & \\
\hline Indigofera linifolia Retz. & rathna maalai & $\begin{array}{l}\text { indian materia medica, volume two, 3rd } \\
\text { edition, } 1954\end{array}$ & 2 \\
\hline Indigofera paucifolia Delile & kauttukkar chammathi & $\begin{array}{l}\text { indian materia medica, volume two, 3rd } \\
\text { edition, } 1954\end{array}$ & \\
\hline Indigofera pulchella Roxb. & narinji & $\begin{array}{l}\text { indian materia medica, volume two, 3rd } \\
\text { edition, } 1954\end{array}$ & 2 \\
\hline Indigofera tinctoria Linn. & averi & $\begin{array}{c}\text { indian materia medica, volume two, 3rd } \\
\text { edition, } 1954\end{array}$ & 2 \\
\hline Indigofera trifoliata Linn. & & $\begin{array}{l}\text { indian materia medica, volume two, 3rd } \\
\text { edition, } 1954\end{array}$ & 2 \\
\hline Indigofera trita Linn & $\begin{array}{c}\text { kandaram, punalmurungai, } \\
\text { saubanjam }\end{array}$ & $\begin{array}{l}\text { indian materia medica, volume two, 3rd } \\
\text { edition, } 1954\end{array}$ & 2 \\
\hline $\begin{array}{l}\text { Indigofera oblongifolia } \\
\text { Forsk }\end{array}$ & kauttukkar chammathi & $\begin{array}{l}\text { Indian Medicinal Plants, vol-1, second } \\
\text { edition, 2012, Periodical expert book } \\
\text { agency, delhi. }\end{array}$ & \\
\hline
\end{tabular}




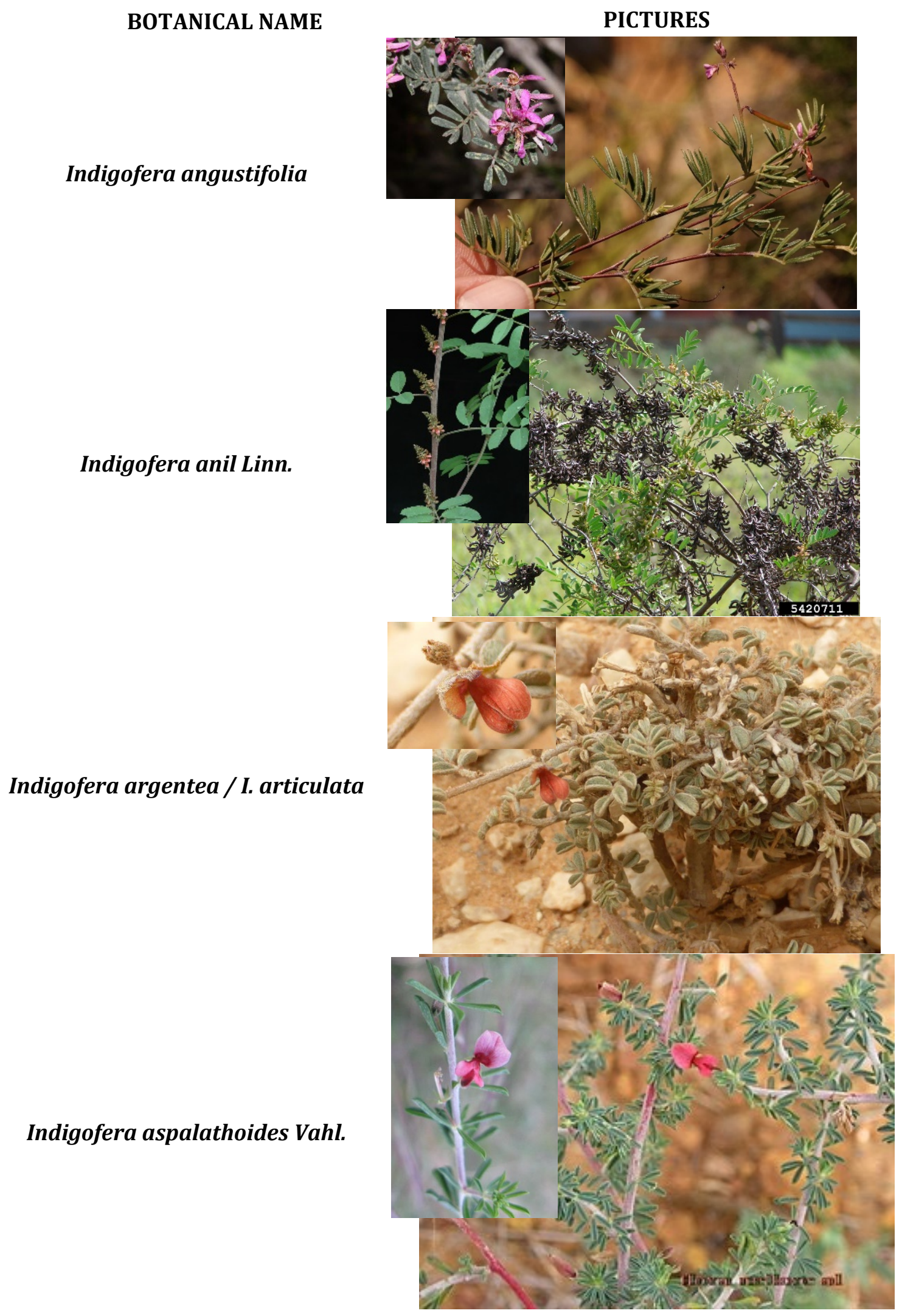




\section{Dr. A. Rajesh}

Indigofera enneaphylla Linn.

Indigofera galegoides $\mathrm{DC}$.

Indigofera glabra Linn.

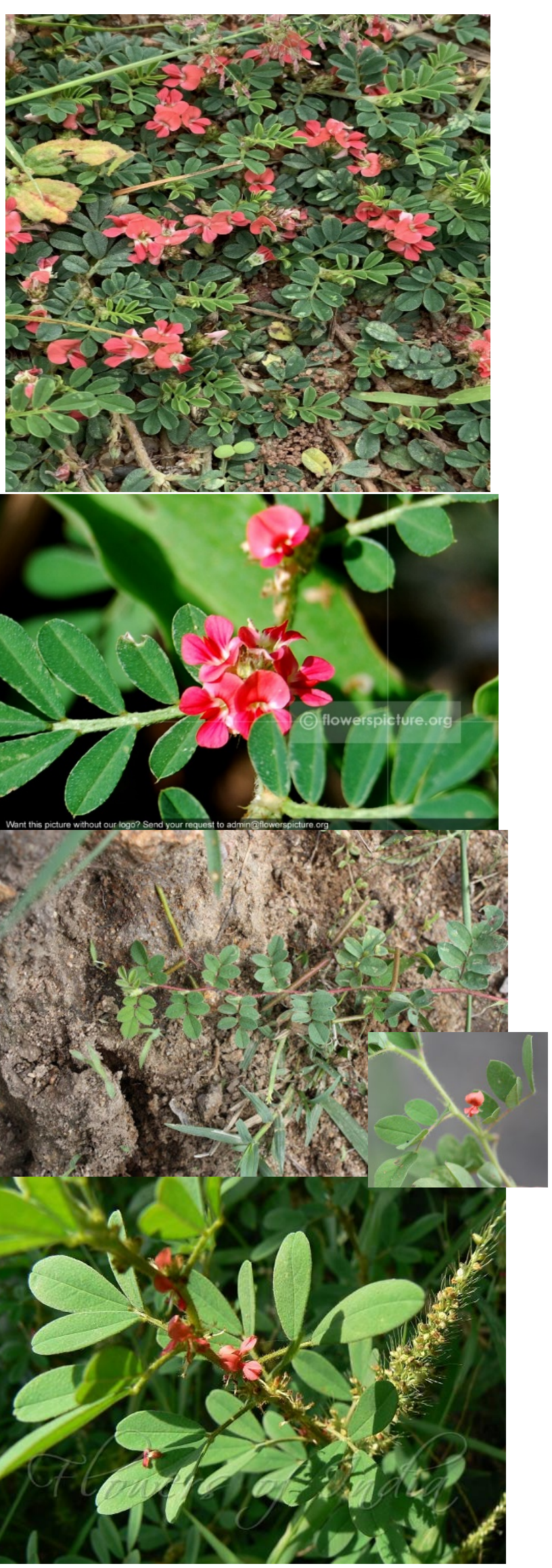


Identified plants which are belongs in Indigofera genera in Thoothukudi District, Tamil Nadu, India

\section{Indigofera indica Gaertn.}

Indigofera linifolia Retz.

\section{Indigofera paucifolia Delile}

Indigofera pulchella Roxb.

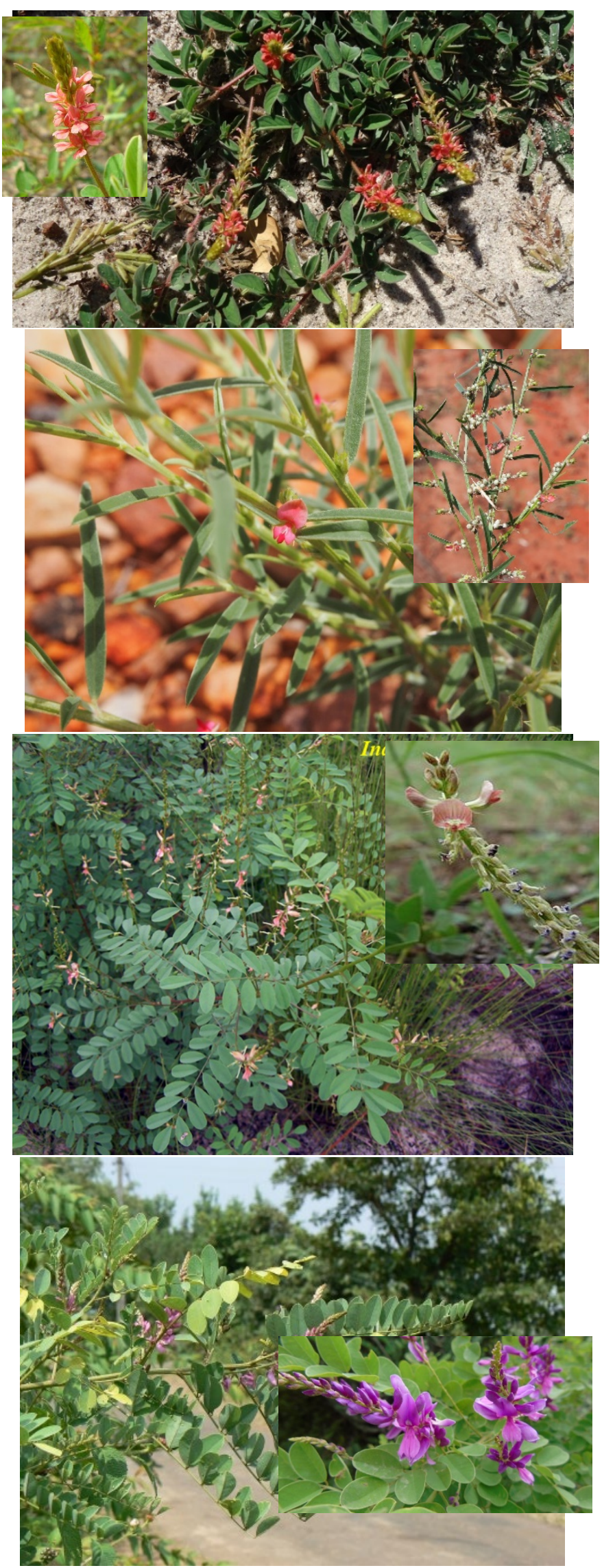


Indigofera tinctoria Linn.

Indigofera trifoliata Linn.

Indigofera trita Linn

Indigofera oblongifolia Forsk

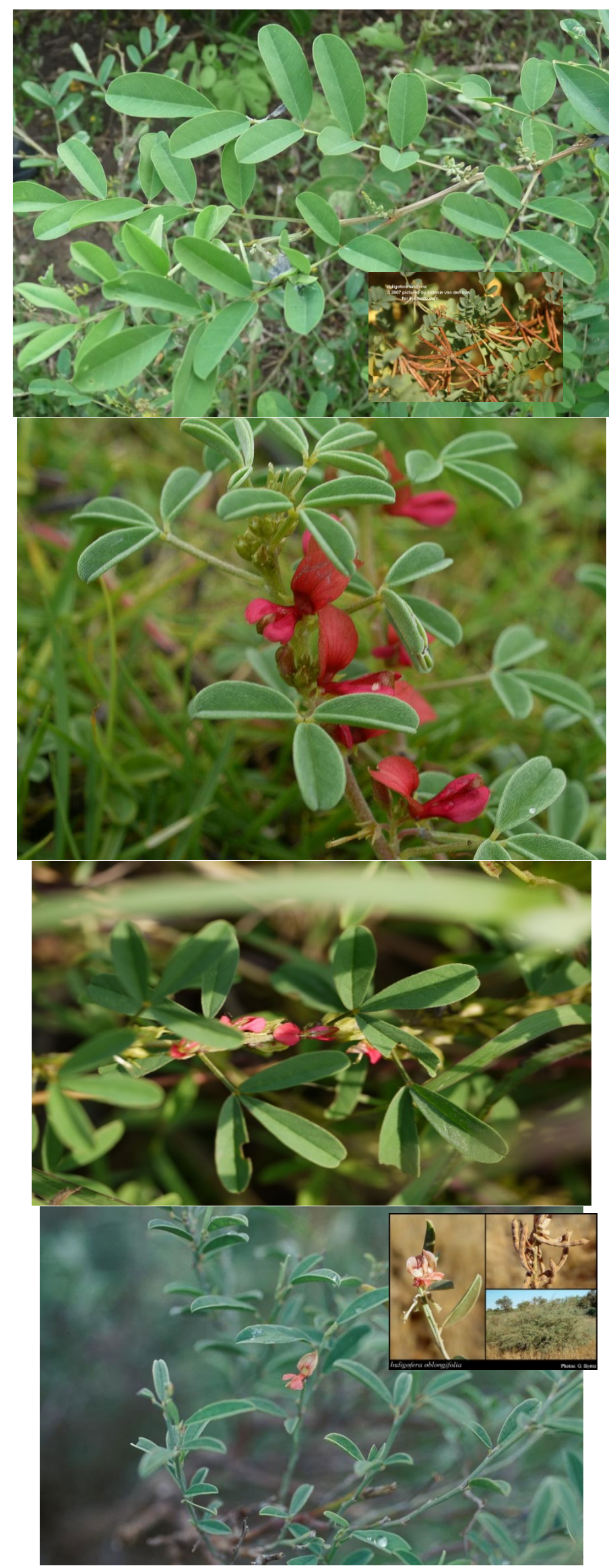




\section{DISCUSSION}

The Indigofera are mostly shrubs, though some are small trees or herbaceous perennials or annuals. Botanical description schedule as; Kingdom: Plantae, (unranked): Angiosperms, (unranked): Eudicots, (unranked): Rosids, Order: Fabales, Family: Fabaceae, Subfamily: Faboideae, Tribe: Indigofereae, Genus: Indigofera. According to the result; 20 species identified in thoothukudi district among 20 species mentioned in two text books such as; Indian Materia Medica, volume two, 3rd edition, 1954 and Indian Medicinal Plants, vol-1, second edition, 2012, Periodical expert book agency, Delhi. That plants were; Indigofera argentea / I. articulate, Indigofera aspalathoides Vahl. Indigofera enneaphylla Linn. Indigofera glabra Linn. Indigofera glandulosa Willd. Indigofera linifolia Retz. Indigofera pulchella Roxb. Indigofera tinctoria Linn. Indigofera trifoliata Linn. Indigofera trita Linn.

Books mentioned 04 species were not latest updated Plant List Online data base which were; Indigofera caerulea Roxb. Indigofera cordifolia, Indigofera frutescens, Indigofera hirsuta.

\section{CONCLUSION}

According to the Results and Discussion this research revealed that, 20 species of Indigofera genera by the evidence of books and 04 species synonyms like updated latest in online data base. However, 16 species available in the Thoothukudi District 16 species available commonly and 04 species were rarely showed in Thoothukudi District by randomly field to all soil types of areas.

\section{SOURCES OF FUNDING}

This research received no specific grant from any funding agency in the public, commercial, or not-for-profit sectors.

\section{CONFLICT OF INTEREST}

The author have declared that no competing interests exist.

\section{ACKNOWLEDGMENT}

I express my thanks to head of the Medicinal Botany Department, Govt. Siddha Medial College, Tirunelveli. And my colleagues from various colleges to help this whole research work.

\section{REFERENCES}

[1] Schrire BD, Lavin M, Barker NP, Forest F. (2009). "Phylogeny of the tribe Indigofereae (LeguminosaePapilionoideae): Geographically structured more in succulent-rich and temperate settings than in grass-rich environments". Am J Bot. 96 (4): 816-52. doi:10.3732/ajb.0800185. PMID 21628237.

[2] Schrire BD. (2008). "The Madagascan genus Vaughania is reduced to synonymy under Indigofera (Leguminosae-Papilionoideae-Indigofereae)". Kew Bulletin. 63 (3): 477-479. doi:10.1007/s12225-0089061-7. JSTOR 20649585.

[3] Gao X, Schrire BD. "Indigofera L." Flora of China. eFloras (Missouri Botanical Garden, St. Louis, MO \& Harvard University Herbaria, Cambridge, MA). Retrieved 12 February 2017.

[4] Paulino J, Groppo M, Teixeira S. (2011). "Floral developmental morphology of three Indigofera species (Leguminosae) and its systematic significance within Papilionoideae". Plant Systematics and Evolution. 292 (3): 165-176. doi:10.1007/s00606-010-0405-z.

[5] Leite V, Marquiafável F, Moraes D, Teixeira S. (2009). "Fruit anatomy of Neotropical species of Indigofera (Leguminosae, Papilionoideae) with functional and taxonomic implications". The Journal of the Torrey Botanical Society. 136 (2): 203-211. doi:10.3159/08-RA-106.1. 
[6] Chauhan V, Pandey A. (2014). "Structure and evolution of the pod in Indigofera (Fabaceae) reveals a trend towards small thin indehiscent pods". Botanical Journal of the Linnean Society. 176 (2): 260-276. doi:10.1111/boj.12203.

[7] Splitstoser JC, Wouters J, Claro A. (2016). "Early pre-Hispanic use of indigo blue in Peru". Science Advances. 2 (9). American Association for the Advancement of Science.

[8] Douma M.. "Pigments through the Ages-History-Indigo". Pigments through the Ages.

[9] Buchanan R. (1999). A Weaver's Garden: Growing Plants for Natural Dyes and Fibers. Courier Corporation. p. 106. ISBN 978-0-486-40712-8. Retrieved 12 May 2016.

[10] Anonymous, "Tico Ethnobotanical Dictionary". Archived from the original on 3 June 2007. Retrieved 16 June 2007.

[11] Anonymous, "(syllabus: Duke University)". Archived from the original on 2015-09-24.

[12] Bhaskar AE, Ganga N, Arivudaimbi R, Santhanum G. (1982). "Anti-inflammatory, analgesic activities of Indigofera aspalthoides". Indian J Med. 76: 115-16.

[13] Leite SP, Silva LLS, Catanho MTJA, Lima EO, Lima VLM. (2003). "Anti-inflammatory activity of Indigofera suffruticosa extract". Rebrasa. 7: 47-52.

[14] Leite SP, Vieira JR, de Medeiros PL, Leite RM, de Menezes Lima VL, Xavier HS, de Oliveira Lima E. (2006). "Antimicrobial Activity of Indigofera suffruticosa". Evid Based Complement Alternat Med. 3 (2): 261-265. doi:10.1093/ecam/nel010. PMC 1475935. PMID 16786057.

[15] Anonymous, "Phytodrug for management of peptic ulcer and methods of preparing and using same."

[16] Bussmann RW, Gilbreath GG, Solio J, Lutura M, Lutuluo R, Kunguru K, Wood N, Mathenge SG. (2006). "Plant use of the Maasai of Sekenani Valley, Maasai Mara, Kenya". J Ethnobiol Ethnomed. 2: 22. doi:10.1186/17464269-2-22. PMC 1475560. PMID 16674830.

[17] Anonymous, "ILDIS Legume Web entry for Indigofera". International Legume Database \& Information Service. Cardiff School of Computer Science \& Informatics. Retrieved 12 February 2017.

[18] Anonymous, USDA, ARS, National Genetic Resources Program. "GRIN species records of Indigofera". Germplasm Resources Information Network-(GRIN) [Online Database]. National Germplasm Resources Laboratory, Beltsville, Maryland. Retrieved 12 February 2017.

[19] Anonymous, "The Plant List entry for Indigofera". The Plant List. Royal Botanic Gardens, Kew and the Missouri Botanical Garden. 2013. Retrieved 12 February 2017.

[20] Anonymous, English Names for Korean Native Plants (PDF). Pocheon: Korea National Arboretum. 2015. p. 497. ISBN 978-89-97450-98-5. Archived from the original (PDF) on 25 May 2017. Retrieved 19 December 2016 - via Korea Forest Service.

[21] Kumar P. (2012). Indigo Plantations and Science in Colonial India. Cambridge University Press. p. 350. ISBN 978-1-107-02325-3.

[22] Anonymous, Indigofera. eFloras Lists.

[23] Dressler, S.; Schmidt, M. \& Zizka, G. (2014). "Indigofera". African plants - a Photo Guide. Frankfurt/Main: Forschungsinstitut Senckenberg.

[24] Nadkarni, indian materia medica, volume two, 3rd edition, 1954

[25] Krithikar and basu, Indian Medicinal Plants, vol-1, second edition, 2012, Periodical expert book agency, Delhi. 